\title{
Sistem Informasi Manajemen Laboratorium Teknik Mesin (Studi Kasus Universitas Muria Kudus Dengan Notifikasi Whatsapp)
}

\author{
Ida Siti Marfuah¹, Nanik Susanti², Supriyono ${ }^{3}$ \\ 1 Informatics System, Muria Kudus University, Kudus, Indonesia \\ 2,3Information System Departement, Muria Kudus University, Kudus, Indonesia \\ E-Mail:1201753095@std.umk.ac.id, 2nanik.susanti@umk.ac.id, 3supriyono.si@umk.ac.id
}

Abstrak

Laboratorium Teknik Mesin Fakultas Teknik merupakan laboratorium yang disediakan oleh Universitas Muria Kudus bertujuan untuk mendorong mahasiswa dalam melaksanakan kegiatan praktikum khususnya praktikum di jurusan Teknik Mesin. Di laboratorium teknik mesin, dalam lingkup input data, komputer masih digunakan sebagai sarana untuk melaksanakan aktivitas yang berkaitan dengan pengelolaan data pendataan jadwal, pengelolaan inventaris, pendataan hasil riset, pendataan Bahan lab, pendataan peminjaman dan pengembalian barang, dan terkadang masih salah karena pendataan masih terus menerus dan belum ada prosedur khusus yang digunakan untuk membuat laporan terkait pengolahan data dan inventarisasi yang berakibat pada keterlambatan pendataan. Sasaran dari observasi ini adalah penulis ingin membangun system yang berjudul "Sistem Informasi Manajemen Laboratorium Teknik Mesin (Studi Kasus Universitas Muria dengan Notifikasi Whatsapp)" maka dari itu diharapkan Ka.lab, Laboran, dan mahasiswa dengan memakai aplikasi ini dapat menjadi pemeahan masalah yang baik untuk mengatasi persoalan dalam memperoleh informasi dan dalam melakukan pengelolaan data. Aplikasi ini dilengkapi dengan fitur notifikasi Whatapps. Dalam observasi ini, penulis menggunakan metode pengembangan waterfall dan menggunakan wawancara, observasi, dan studi literatur/pustaka sebagai hasil dari analisis kebutuhan. Hasil analisis perancangan sistem menggunakan pemodelan UML (Unified Modeling Language), yang kemudian diimplementasikan dalam sistem aplikasi berbasis WEB, dan menggunakan PHP dalam perancangan serta menggunakan database MySQL.

Kata Kunci : Manajemen, Laboratorium, Whatsapp, Waterfall, PHP, Mysql.

\section{PENDAHULUAN}

Di era globalisasi sekarang ini, perkembangan teknologi yang pesat telah memberikan banyak manfaat bagi kemajuan di segala bidang, khususnya di bidang teknologi informasi. Pada dasarnya teknologi informasi merupakan 
https://journal-computing.org/index.php/journal-ita/index

teknologi yang digunakan untuk mengelola data, seperti memperoleh, mengolah, menyusun, menyimpan dan memanipulasi data dengan berbagai cara sehingga akan menghasilkan informasi yang bermutu, relevan, akurat dan tepat waktu di masa yang akan datang. Salah satu perkembangan teknologi informasi adalah penggunaan sistem komputerisasi, yang saat ini digunakan hampir di semua lingkungan kerja untuk menghasilkan dan menyediakan informasi yang sesuai. Oleh karena itu, teknologi informasi dan komunikasi telah menjadi kebutuhan dalam segala aspek kehidupan untuk mempermudah dan mempercepat proses operasional yang ada di instansi dan perusahaan terkait.

Laboratorium Teknik Mesin Fakultas Teknik Universitas Muria Kudus merupakan laboratorium yang disediakan oleh Universitas Muria Kudus bertujuan untuk mendorong mahasiswa dalam melaksanakan kegiatan praktikum khususnya praktikum di jurusan Teknik Mesin Universitas Muria Kudus yang beralamatkan di Jln. Lingkar Utara, Kayuapu Kulon, Gondangmanis, Kec. Bae, Kabupaten Kudus, Jawa Tengah 59327. Laboratorium Teknik mesin tidak hanya digunakan untuk praktikum, tetapi juga digunakan untuk kegiatan tugas terstruktur pada berbagai mata kuliah di jurusan Teknik Mesin. Laboratoium Teknik Mesin sendiri dikelola oleh KA.Lab dan 5 laboran di Laboratorium TM terdapat 16 lab yaitu lab pengecoran, lab pembentukan logam, lab permesinan, lab kerja bangku, lab pengujian bahan, lab motor bakar, lab pengelasan, lab pneumatic dan hidrolik, lab fluida, lab. Sistem control, lab fisika, lab gambar, lab metrology, lab desain, lab CAE dan lab CNC.

Pada laboratorium Teknik Mesin dimana komputer masih sebagai sarana untuk mengerjakan kegiatan-kegiatan yang berkaitan dengan administrasi maupun manajemen, dalam sebatas untuk mengetik Data pendataan jadwal, pengelolaan inventaris, pendataan hasil riset, pendataan bahan lab, pendataan peminjaman alat kadang masih terdapat kesalahan dikarenakan pendataan masih dilakukan secara manual dan Belum menggunakan prosedur khusus untuk menghasilkan laporan terkait pengolahan data dan inventaris, sehingga terjadi keterlambatan pendataan asisten dosen, penjadwalan praktikum, peminjaman dan pengembalian alat. Oleh karena itu, dalam penelitan ini penulis ingin membuat system yang berjudul "Sistem Informasi Manajemen Laboratorium berbasis Web Responsive menggunakan Notitikasi Whatapss di Program Studi Teknik Mesin Universitas Muria Kudus" maka dari itu diharapkan Ka.lab, Laboran, Dosen dan mahasiswa menggunakan aplikasi ini menjadi solusi yang baik untuk mengatasi permasalahan dalam memperoleh informasi dan dalam melakukan pengelolaan data.

Berdasarkan uraian latar belakang yang telah diuraikan diatas, maka penulis merumuskan suatu masalah yaitu bagaimana merancang dan membangun 
https://journal-computing.org/index.php/journal-ita/index

"Sistem Informasi Manajemen Pengelolaan Laboratorium Pada Program Studi Teknik Mesin Universitas Muria Kudus Berbasis Web" sehingga membantu mengoptimalkan dalam hal mengajar dan belajar serta membantu Ka.lab, Laboran, dan Mahasiswa dalam memperoleh data peralatan, data mahasiswa, data penjadwalan laboratorium, data peminjaman alat, data hasil riset mahasiswa, data inventaris lab, dan data bahan lab.

Agar permasalahan dapat lebih terarah pada pembahasan yang diangkat dan sesuai tujuan awalnya serta tak mengurangi efektifitas pemecahannya, maka dalam penelitian ini perlu adanya batasan sebagai berikut :

1. Sistem aplikasi yang akan di buat hanya digunakan untuk pengelolaan laboratorium yang ada pada Program Studi Teknik Mesin Universitas Muria Kudus.

2. Sistem ini dilengkapi dengan notifikasi whatapps untuk memudahkan mahasiswa, laboran dan Ka. Lab Teknik Mesin dalam mendapatkan informasi tentang kegiatan yang ada di laboratorium .

3. Ka.Lab dapat melihat atau memantau kegiatan apa saja yang dilakukan di laboratorium yang nantinya akan di tampilkan dari sistem.

4. Sistem Informasi Manajemen laboratorium disini mencakup tentang data dosen, data mahasiswa, data penjadwalan laboratorium, data peminjaman alat, data hasil riset, data inventaris lab, dan data bahan lab.

5. SIM-LAB ini untuk peminjaman alat, peminjaman laboratorium, hasil lab khusus hanya untuk mahasiswa Teknik mesin.

6. WEB yang dibuat dapat diakses oleh kaprodi, ka laboratorium, laboran, dan mahasiswa Teknik mesin.

7. Informasi atau output yang di hasilkan adalah laporan data penggunaan laboratorium mulai dari penjadwalan baik dengan hasil riset mahasiswa dan juga laporan peminjaman alat dan lab di laboratorium TM.

\section{LANDASAN TEORI}

\subsection{Sistem Informasi}

System informasi adalah sistem dalam sebuah organisasi yang mempertemukan kebutuhan pengolahan transaksi harian yang membantu fungsi operasi organisasi untuk dapat dipersiapkan kepada pihak luar tertentu dengan informasi yang diperlukan untuk pengambilan keputusan. Sistem informasi dalam suatu organisasi dapat dikatakan sebagai suatu sistem yang menyediakan informasi yang kapan saja dapat diperlukan bagi semua tingkatan dalam organisasi tersebut (Anggraeni \& Irviani, 2017). 
Journal of Information Technology Ampera

Vol. 2, No. 3, December 2021 e-ISSN: 2774-2121

https://journal-computing.org/index.php/journal-ita/index

\subsection{Manajemen}

Menurut (Ahmad \& Munawir, 2018), Bahwa manajemen disimpulkan menjadi dua yaitu manajemen sebagai proses dan manajemen sebagai subjek. Sebagai Proses, manajemen adalah suatu kegiatan yang dilakukan untuk menyelesaikan suatu pekerjaan bersama atau mengaitkan dengan orang lain untuk mencapai tujuan yang sama. Sedangkan, Sebagai Subjek, manajemen adalah orang-orang yang melakukan pekerjaan dan semua sumber daya lain yang tersedia.

\subsection{Manajemen Laboratorium}

Dalam Buku Manajemen laboratorium (Astuti, 2020), menyatakan bahwa manajemen laboratorium atau yang biasa disebut pengelolaan laboratorium adalah suatu kegiatan dalam perencanaan, perawatan, pengamanan, dan pengadministrasian untuk peningkatan laboratorium secara efektif dan efisien untuk mencapai suatu tujuan.

\section{METODE PENELITIAN}

\subsection{Metode pengumpulan data}

Agar di peroleh data yang lebih relevan, akurat, reliable, dan akurat, maka penulis menggunakan metode pengumpulan data sebagai berikut:

A. Teknik Observasi, Untuk mencari data yang dibutuhkan, penulis juga menghamiri lokasi objek oberservasi untuk melihat dan mengamati secara langsung proses. Data yang didapatkan dari observasi ini yaitu data inventaris, data bahan lab, data laboratorium, data mahasiswa, data dosen, data peminjaman alat dan data peminjaman laboratorium dan data jadwal, dan data hasil riset mahasiswa.

B. Teknik Wawancara, Teknik wawancara dilakukan dengan menanyakan kepada kepala laboratorium yakni Bpk. Hera Setiawan S.T., M.T. dan laboran yakni Bpk. Setiawan Harmoko, S.T dan Bpk. Hariyanto, S.T mengenai proses bisnis yang berjalan, manajemen pengelolaan meliputi data dosen, data mahasiswa, data penjadwalan laboratorium, data peminjaman alat, data hasil riset mahasiswa, data inventaris lab, dan data bahan lab.

\subsection{Metode pengembangan sistem}

Metode air terjun (Waterfal) adalah proses pengembangan perangkat lunak sekuensial di mana perkembangan dilihat sebagai aliran turun terus menerus 
(seperti air terjun) dalam berbagai tahap perencanaan, pemodelan, implementasi (konstruksi), dan pengujian. Metode waterfall memiliki beberapa tahapan yang berurutan dalam proses pengembangannya: persyaratan (analisis kebutuhan), desain sistem (desain sistem), pengkodean dan pengujian, implementasi program, dan pemeliharaan. (Yurindra, 2017).

1. analisis kebutuhan, Pada tahap ini merupakan tahap pengumpulan data yang dapat dilakukan dengan melakukan penelitian, wawancara atau penelitian kepustakaan.

2. Desain, Tahap ini merupakan Proses desain pembuatan program perangkat lunak

3. Penulisan kode program, Tahap ini merupakan proses translasi desain ke dalam bahasa yang dapat dikenali komputer atau yang disebut coding.

4. Penerapan / Pengujian Program, Tahapan ini merupakan pengujian terhadap perangkat lunak untuk meminimalisir kesalahan dan memastikan program sesuai dengan kebutuhan.

5. Pemeliharaan, Tahap ini merupakan tahap Pengujian Perangkat lunak yang mungkin terjadi karena kesalahan, perangkat lunak harus beradaptasi atau karena pelanggan memerlukan pengemban

\section{HASIL DAN PEMBAHASAN}

\subsection{Analisa Kebutuhan Data dan Informasi}

Untuk membangun sebuah sistem dibutuhkan adanya masukan berupa data yang nantinya akan diproses oleh sistem sehingga sistem dapat memberikan sebuah informasi yang bermanfaat kepada penggunanya. Kebutuhan data dan informasi untuk sistem ini adalah sebagai berikut:

1. Kebutuhan data yang diperlukan antara lain:
a. Data User (Penguna Sistem)
b. Data mahasiswa
c. Data Peralatan/bahan
d. Data Laboratorium
e. Data Dosen
f. Data Matakuliah
g. Data Bahan Masuk dan Keluar
h. Data inventaris
i. Data Peminjaman Alat
j. Data penjadwalan
k. Data peminjaman lab
I. Data pengumpulan hasil riset/tugas akhir 
https://journal-computing.org/index.php/journal-ita/index

2. Kebutuhan Informasi yang diperlukan antara lain:

a. Informasi data invertaris, data Bahan Masuk, data bahan keluar, data peminjaman alat, penjadwalan lab, dan penggumpulan hasil tugas akhir mahasiswa.

b. Laporan data inventaris, Bahan Masuk dan bahan keluar.

c. Laporan peminjaman Alat.

d. Laporan pengumpulan hasil tugas akhir mahasiswa.

\subsection{Analisa aktor system}

Aktor menggambarkan semua pengguna sistem. Aktor dalam Sistem Informasi Manajemen Laboratorium Pada Program Studi Teknik Mesin Universitas Muria Kudus antara lain sebagai berikut:

1. Ka Lab

Bagian Ka Lab ini memiliki hak akses untuk mengelola management sytem yaitu kelola data user dan periode, dan melihat data laporan bahan masuk, data inventaris, peminjaman alat, penjadwalan lab dan hasil riset mahasiswa. Selain itu Ka Lab juga dapat memeriksa persediaan bahan untuk praktikum melalui data bahan masuk dan melihat serta mencetak laporan.

2. Laboran

Bagian Laboran ini memiliki hak akses untuk mengelola data dosen, data mahasiswa, data matakuliah, data laboratorium, data bahan lab, data inventaris, data peminjaman alat, peminjaman lab, data penjadwalan, data hasil riset tugas akhir mahasiswa.

3. Mahasiswa

Mahasiswa ini memiliki hak akses untuk melakukan peminjaman lab dan pengumpulan hasil riset/tugas akhir.

4. Dosen

Dosen ini memiliki hak akses untuk melakukan peminjaman lab.

5. Kaprodi

Kaprodi ini memiliki hak akses untuk melihat serta mencetak laporan.

\subsection{System use case}

Diagram sistem use case akan menjelaskan mengenai siapa saja yang terlibat dalam sistem (aktor) dan apa saja yang dikerjakan oleh sistem (use case). Dari proses business use case maka dapat digambarkan proses sistem use case dari Sistem Informasi Manajemen Laboratorium Pada Program Studi Teknik Mesin. Adapun diagram sistem use case yang terbentuk dapat dilihat pada gambar 4.1 berikut ini. 
Journal of Information Technology Ampera

Vol. 2, No. 3, December 2021 e-ISSN: 2774-2121

https://journal-computing.org/index.php/journal-ita/index

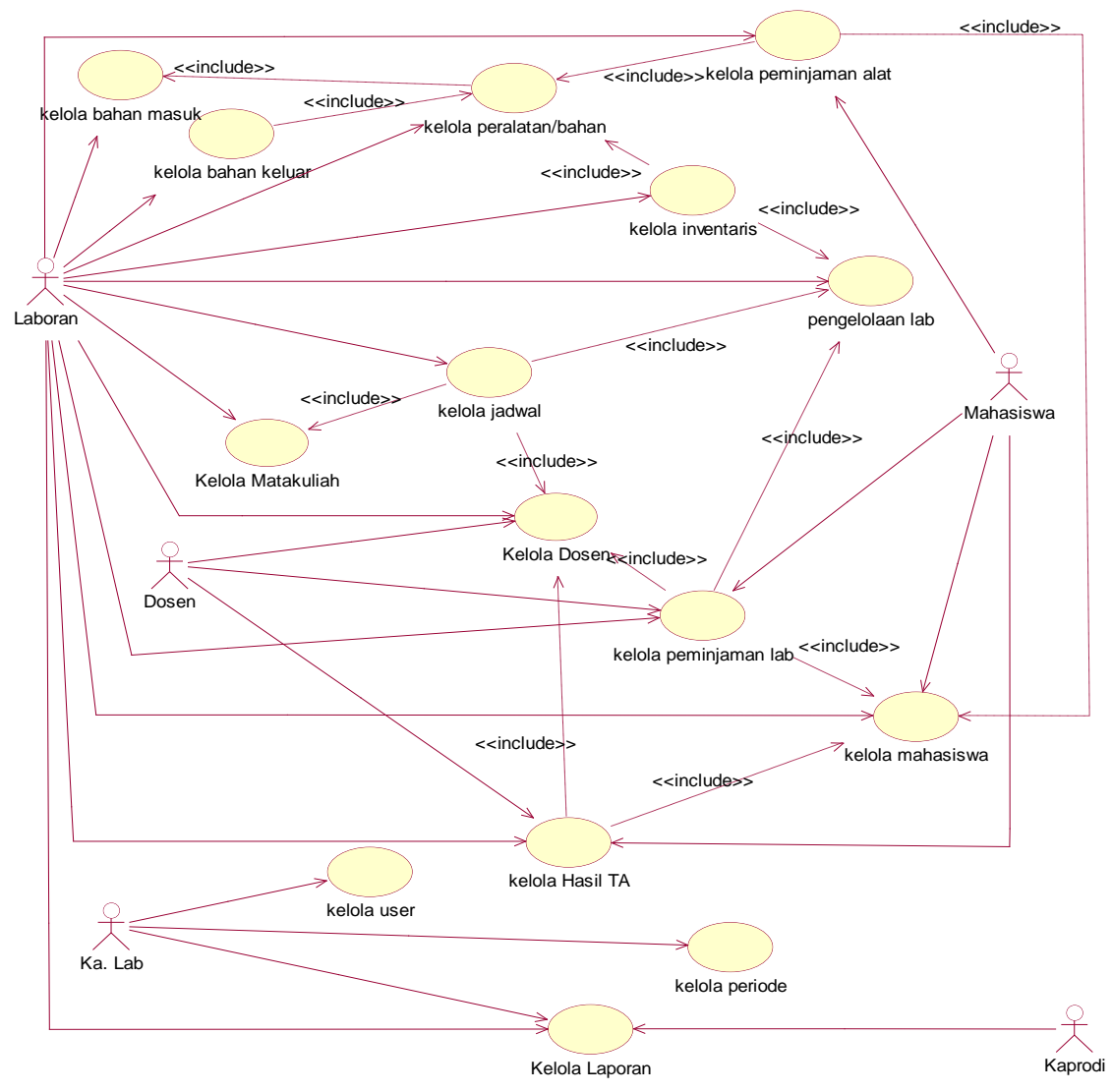

Gambar 4. 1 System Use Case

4.4 Pembuatan Database
a. User
\{user_id, level, nama, username, password,
b. alat/bahan
c. Lab
d. Mahasiswa no_hp, alamat, aktif, ket, foto $\}$
\{alatbahan_id, kode, nama, satuan, qty, jenis\} \{lab_id, kode, nama, ket\}
\{mahasiswa_id, nim, nama_mahasiswa, jekel, alamat, no_hp, foto_ktm\}
e. Inventaris
f. Dinventaris
\{inventaris_id, kode, periode_id, alatbahan_id, lab_id, status
\{dinventaris_id, inventaris_id, tgl_permulai,
g. Periode tgl_perselesai, status, ket $\}$ \{periode_id, kode, nama_periode, ket\} 

h. Dosen
i. Mata kuliah
j. Bahan Masuk
k. Bahan keluar
I. Peminjaman alat
m. Dpinjamalat
n. Peminjaman lab
o. Penjadwalan
p. Hasil riset/TA
\{dosen_id, NIDN/nip, nama_dosen, jekel, alamat, no_hp, foto_identitas $\}$
\{matakuliah_id,
kode_matakuliah, nama_matakuliah, sks\}
\{bahanmasuk_id, kode,periode_id alat/bahan_id, qty, tgl_masuk\}
\{bahankeluar_id, alat/bahan_id, tgl_keluar, qty, ket\}
\{peminjaman_id, kode, periode_id, mahasiswa_id, tgl_pinjam, tgl_kembali, ket_pinjam, ket_kembali, status\}
$\{$ dpeminjaman_id, peminjaman_id, inventaris_id, qty\}
$\{$ labpinjam_id, periode_id, mahasiswa_id, dosen_id, lab_id, bukti, tgl pinjam, jam_mulai, jam_selesai,peminjam, ket, konfirmasi\} \{jadwal_id, periode_id, lab_id, hari, jam_mulai, jam_selesai, matakuliah_id, dosen_id, asdos, ket\} $\{$ hasillab_id, lab_id, periode_id, mahasiswa_id, judul, isi, tgl, foto, ket\}

\subsection{Relasi Tabel}

Relasi tabel pada basis data yang terbentuk untuk pembuatan Sistem Informasi Manajemen Laboratorium Teknik Mesin (Studi Kasus Universitas Muria Kudus dengan notifikasi WhatsApps)..

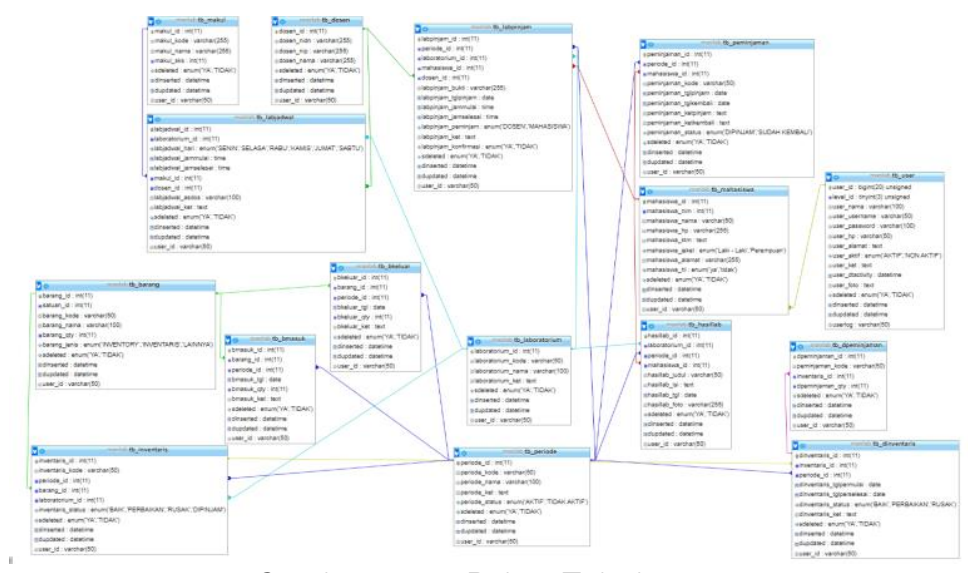

Gambar 4. 2 Relasi Tabel 
Journal of Information Technology Ampera

Vol. 2, No. 3, December 2021 e-ISSN: 2774-2121

https://journal-computing.org/index.php/journal-ita/index

\section{IMPLEMENTASI}

\subsection{Halaman Landing Page}

Berikut ini adalah halaman Page Landing yang dapat di gunakan sebagai halaman awal aplikasi.
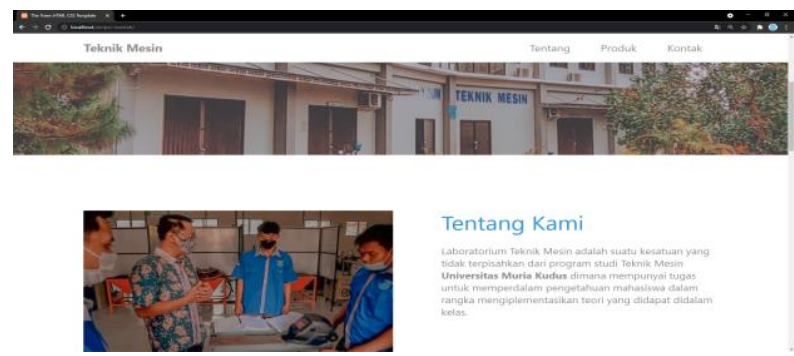

Tentang Kami

Gambar 5. 1 Halaman Landing Page

5.2 Halaman Login

Berikut ini adalah halaman Login yang dapat di gunakan untuk masuk kedalam sistem.

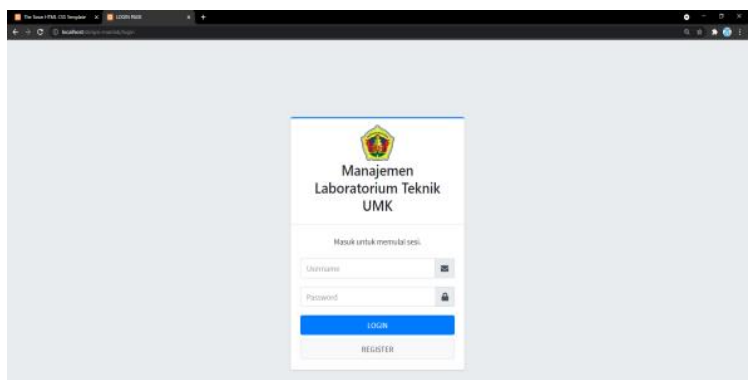

Gambar 5. 2 Halaman Login

5.3 Halaman Dashboard Mahasiswa

Halaman Dashboard Mahasiswa ini digunakan mahasiswa untuk melihat Riwayat mahasiswa.
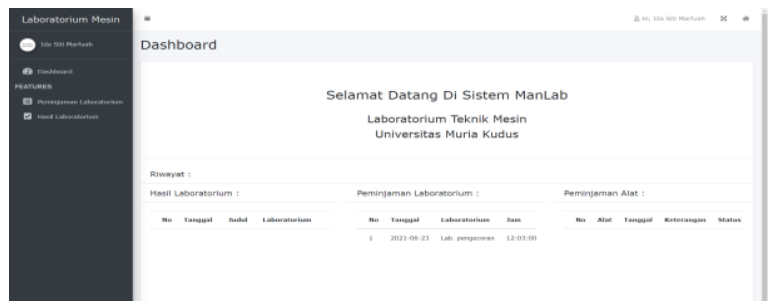

Gambar 5. 3 Halaman Dashboard Mahasiswa 
Journal of Information Technology Ampera

Vol. 2, No. 3, December 2021 e-ISSN: 2774-2121

https://journal-computing.org/index.php/journal-ita/index

5.4 Halaman Dashboard Laboran

Halaman Dashboard ini digunakan laboran untuk melihat tampil informasi.

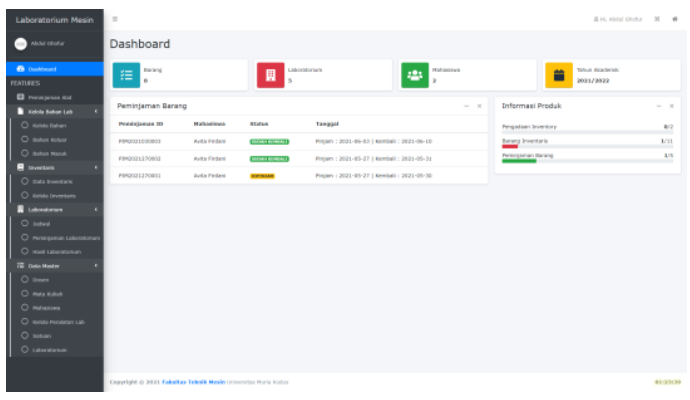

Gambar 5. 4 Halaman Dashboard Laboran

5.5 Halaman Peminjaman lab

Halaman peminjaman lab ini digunakan mahasiswa untuk meminjam laboratorium.

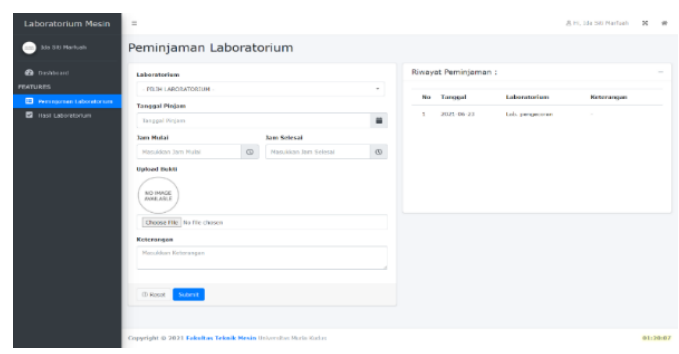

Gambar 5. 5 Halaman Peminjaman lab

5.6 Halaman Menu Hasil Lab

Halaman ini digunakan mahasiswa untuk kelola data Hasil Lab.

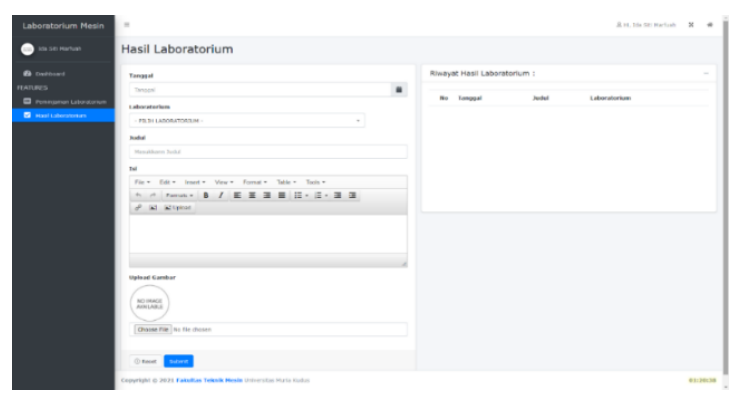

Gambar 5. 6 Halaman Hasil Lab 
Journal of Information Technology Ampera

Vol. 2, No. 3, December 2021 e-ISSN: 2774-2121

https://journal-computing.org/index.php/journal-ita/index

5.7 Halaman Menu Peminjaman alat

Halaman ini digunakan peminjaman alat untuk kelola data dosen.

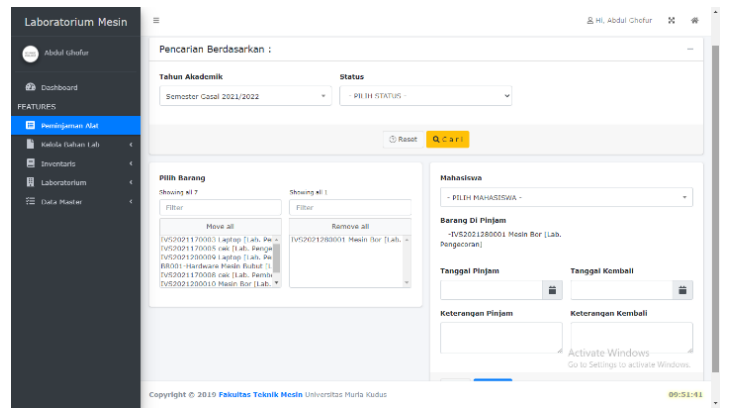

Gambar 5. 7 Halaman Peminjaman Alat

5.8 Halaman Menu Jadwal

Halaman ini digunakan mahasiswa untuk kelola data Jadwal

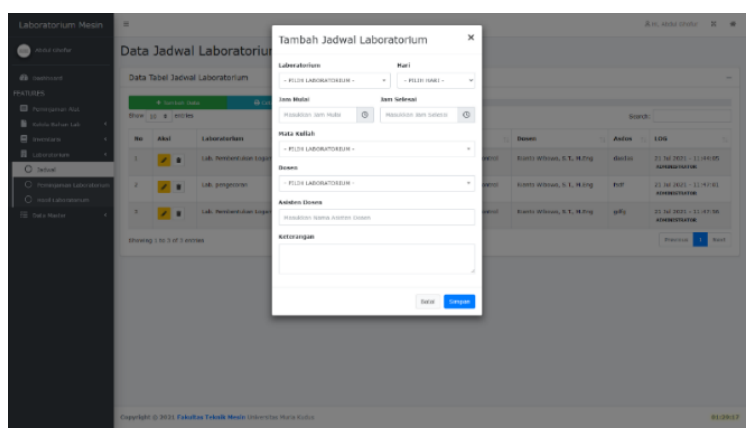

Gambar 5. 8 Halaman Jadwal

5.9 Halaman Laporan Peminjaman Alat

Halaman ini digunakan kaprodi untuk mencetak laporan.

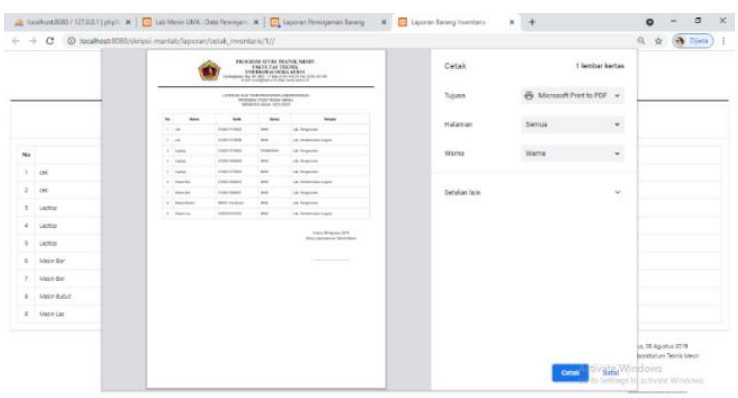

Gambar 5. 9 Halaman Laporan Peminjaman Alat 
Journal of Information Technology Ampera

Vol. 2, No. 3, December 2021 e-ISSN: 2774-2121

https://journal-computing.org/index.php/journal-ita/index

6

KESIMPULAN

Berdasarkan hasil analisa dan perancangan, implementasi, serta uraian yang telah di jelaskan di setiap bab-bab diatas dapat diambil beberapa kesimpulan sebagai berikut:

1. Penelitian ini telah menghasilkan sebuah sistem informasi dengan nama sistem informasi manajemen laboratorium Teknik mesin

2. Pembuatan sistem ini digunakan untuk pengelolaan data dosen, mahasiswa, matakuliah, laboratorium, peralatan/bahan lab, bahan masuk, bahan keluar, inventaris, penjadwalan laboratorium, peminjaman alat, peminjaman laboratorium, pengumpulan hasil riset mahasiswa dan mencetak laporan akhir dari data yang telah tersimpan. Pada sistem ini proses registrasi mahasiswa, dosen, peminjaman lab, dan pengumpulan hasil riset selain terdapat di akses di web, juga dapat diberitahukan melalui notifikasi whatapps. Sistem ini menggunakan tampilan menu yang responsive dan sederhana yang dapat diakses menggunakan PC maupun Smartphone.

3. Informasu yang dihasilkan dapat berupa laporan yang dapat diakses secara online dan realtime.

4. Sistem ini telah dibagun dengan menggunakan bahasa pemrograman PHP dengan Framework Codeighniter dengan database MySql untuk mengelola manajemen laboratorium pada program studi Teknik Mesin Universitas Muria kudus.

DAFTAR PUSTAKA

[1] Ahmad, L., \& Munawir. (2018). Sistem Informasi Manajemen : Buku Referensi (1 ed.). (Syarifuddin, Ed.) Banda Aceh: LEMBAGA KOMUNITAS INFORMASI TEKNOLOGI ACEH (KITA).

[2] Alkodri, A. (2018). Rancang Bangun Sistem Informasi Manajemen Laboratorium Komputer Berbasis Website: Studi Kasus STMIK ATMA LUHUR. Konferensi Nasional Sistem Informasi 2018, 1006-1011.

[3] Anggraeni, E. Y., \& Irviani, R. (2017). Pengantar Sistem informasi. Yogyakarta: ANDI.

[4] Arsa, I. G. (2015). Analisis Dan Perancangan Sistem Informasi Manajemen Laboratorium STMIK STIKOM Bali Berbasis Web. JURNAL SISTEM DAN INFORMATIKA, 87-98.

[5] Astuti, R. (2020). Manajemen Laboratotium yang Cerdas, cermat, dan Selamat. Jawa Barat: CV Jejak; Anggota IKAPI;. 
[6] Garside, A. K., \& Utama, D. M. (2016). Perancangan Sistem Informasi Laboratorium Teknik Industri Universitas Muhammadiyah Malang. Seminar Nasional Teknologi dan Rekayasa, 6-11.

[7] Oktapiani, I., Hananto, A. L., \& Retnosary, R. (2020). Sistem Informasi Manajemen Aset Laboratorium Komputer Berbasis Web Menggunakan Model Waterfall. Conference on Innovation and Application of Science and Technology , 409-418.

[8] Suseno, N., Partono, R., Harjati, P., \& HA, D. (2018). School Laboratory Management Information System. Physics: Conference Series 1st International Conference of SNIKOM, 1-8. doi:10.1088/1742$6596 / 1361 / 1 / 012068$

[9] Tejesh, B. S., \& Neeraja, S. (2018). Warehouse inventory management system using. Alexandria Engineering Journal, 3817-3823.

[10] Tone, K. (2017). Sistem Pengelolaan Manajemen Laboratorium Komputer Jurusan Sistem Informasi Uin Alauddin MakassaR. INSTEK, 121-129.

[11] Yurindra. (2017). Software Engineering Pendekatan Proses Model Perangkat Lunak, Pendekatan Model Proses Kematangan \& Penilaian Perangkat Lunak. Yogyakarta: Deepublish (Grup Penerbitan CV Budi Utama). Retrieved Maret 3, 2020 